\title{
Knowledge and attitude regarding standard precautions in a Brazilian public emergency service: a cross-sectional study
}

\author{
CONHECIMENTO E ATITUDE SOBRE PRECAUÇÕES-PADRÃO EM UM SERVIÇO \\ PÚBLICO DE EMERGÊNCIA BRASILEIRO: UM ESTUDO TRANSVERSAL
}

\author{
CONOCIMIENTO Y ACTITUD SOBRE LAS PRECAUCIONES ESTÁNDAR EN UN \\ SERVICIO PÚBLICO DE EMERGENCIA BRASILEÑO: UN ESTUDIO TRANSVERSAL
}

\author{
Adriana Cristina Oliveira ${ }^{1}$, Maria Helena Palucci Marziale ${ }^{2}$, \\ Maria Henriqueta Rocha Siqueira Paiva ${ }^{3}$, Aline Cristine Souza Lopes ${ }^{4}$
}

\begin{abstract}
The purpose of this study was to assess the knowledge and attitude of health care professionals regarding their use of universal precaution measures at a public emergency service. The study also aimed to assess the rates of occupational accidents involving biological substances among those workers. This study was performed with 238 workers, from June to November 2006, using univariate and multivariate analysis. The chance of not adopting precaution measures was 20.7 ( $95 \% \mathrm{Cl}$ : 5.68 - 75.14) times greater among drivers compared to physicians. No significant association was found between adopting universal precaution measures. The occupational accident rate was $20.6 \%$ (40.8\% involving sharp-edged objects). The risk of physicians having an occupational accident was $2.7(95 \% \mathrm{Cl}: 1.05$ - 7.09) times higher than that of drivers. The fact that a staff member had adequate knowledge about universal precaution measures was insufficient to foster compatible attitudes towards reducing the risk of transmitting infectious agents and causing occupational accidents.
\end{abstract}

\section{KEY WORDS}

Emergencies.

Accidents, occupational.

Accident prevention.

Occupational health.

Patient care team

\begin{abstract}
RESUMO
Objetivou-se avaliar a adoção das medidas de precaução padrão por meio de conhecimento e atitude dos profissionais de um serviço público de emergência, assim como a incidência de acidentes de trabalho envolvendo material biológico entre tais profissionais. A pesquisa foi realizada com 238 profissionais entre Junho e Novembro de 2006. Utilizou-se análise univariada e multivariada. A possibilidade de não-adoção das medidas de precaução foi 20.7 ( $95 \% \mathrm{Cl}$ : 5,68 - 75,14 ) vezes maior entre motoristas, quando comparados aos médicos. Não houve associação significante entre a adoção às medidas de precaução padrão. A incidência de acidentes de trabalho foi $20.6 \%$ (40.8\% envolvendo material pérfuro-cortante). 0 risco de médicos terem um acidente de trabalho foi $2.7(95 \% \mathrm{Cl}: 1.05$ - 7.09) vezes maior que os condutores. $\mathrm{O}$ fato de os membros da equipe apresentarem conhecimentos adequados sobre as medidas de precaução padrão foi insuficiente para promover atitudes compatíveis a fim de reduzir o risco de transmissão de agentes infecciosos e acidentes de trabalho.
\end{abstract}

\author{
DESCRITORES \\ Emergências. \\ Acidentes de trabalho. \\ Prevenção de acidentes. \\ Saúde do trabalhador. \\ Equipe de assistência ao paciente.
}

\section{RESUMEN}

El estudio tuvo como objetivo evaluar la adopción de medidas de precaución estándar por medio del conocimiento y actitud de los profesionales de un servicio público de emergencia; también evaluar la incidencia de accidentes de trabajo con material biológico entre esos profesionales. La investigación fue realizada con 238 profesionales entre Junio y Noviembre de 2006. Se utilizó el análisis univariado y multivariado. La posibilidad de no adoptar las medidas de precaución fue de 20.7 (95\%Cl: 5,68 -75,14) veces mayor entre los choferes en comparación con los médicos. No hubo asociación significativa entre la adopción de las medidas de precaución estándar. La incidencia de accidentes de trabajo fue $20.6 \%$ (40.8\% con material punzo cortante). El riesgo de los médicos de sufrir un accidente de trabajo fue $2.7(95 \% \mathrm{Cl}: 1.05$ - 7.09) veces mayor que los choferes. El hecho de que los miembros del equipo hubiesen presentado un conocimiento adecuado sobre las medidas de precaución estándar fue insuficiente para promover actitudes compatibles para reducir el riesgo de transmisión de agentes infecciosos y accidentes de trabajo.

\section{DESCRIPTORES}

Urgencias médicas.

Accidentes de trabajo.

Prevención de accidentes.

Salud laboral.

Grupo de atención al paciente

${ }^{1}$ RN. PhD. Professor at Department of Basic Nursing, College of Nursing, Federal University of Minas Gerais. Belo Horizonte, MG, Brazil. acoliveira@ufmg.br ${ }^{2}$ Professor at Departament of General and Specialized Nursing, College of Nursing, University of São Paulo. Ribeirão Preto, SP, Brazil. marziale@eerp.usp.br ${ }^{3}$ RN. MSc. Public Pre-hospital Care. Belo Horizonte, MG, Brazil. mariahenriquetarsp@yahoo.com.br ${ }^{4}$ PhD. Professor at Department of Basic Nursing, College of Nursing, Federal University of Minas Gerais. Belo Horizonte, MG, Brazil. aline@medicina.ufmg.br 


\section{INTRODUCTION}

Public emergency services offer health care services to people with any sudden illness or traumas until they reach a specialized facility ${ }^{(1)}$. Over the last years, there has been an increase in the search for emergency services worldwide due to the number of accidents, cases of violence, and acute diseases $^{(1-2)}$. This fact has caused a fast growth in the number of emergency services and, therefore, public departments, such as the centers for disease control (CDC) and the occupational safety and health administration (OSHA), to oversee the workers' safety and health as well as to provide specialized training on universal precaution measures ${ }^{(3)}$.

This service often exposes professionals to body fluids, which are likely to transmit diseases, mainly viral infections, like hepatitis $B$ and $C$, and acquired immune deficiency syndrome ${ }^{(3-4)}$.

The workload in this service, as well as the negligence in using precaution measures, such as using individual protection equipment (IPE), handwashing, promoting vaccination against Hepatitis $B$, and appropriately disposing sharp-edged objects are all important factors that cause or increase health workers' risk of accidents ${ }^{(5-6)}$.

Studies have shown that the failure to comply with precaution measures is associated with the health professionals' knowledge and attitude, the lack of knowledge in this area, insufficient preparation to deal with the clientele, their belief that it the risk is a regular part of their work, disregarding the patients' health conditions, lack of support from the population and institutions who should provide their safety, an accelerated cadence of assignments and care services ${ }^{(7-9)}$.

Within this context, few studies have been performed in Brazil with the aim to assess emergency service professionals' knowledge and attitudes regarding precaution measures, occupational risks, and specific care, like infection control.

Therefore, this study aimed to assess the knowledge level and attitudes of the multiprofessional team of a public emergency health service with the purpose to identify the factors that affect adopting those measures and establish the rate for occupational accidents involving biological substances.

\section{METHOD}

This cross-sectional survey was performed between June and November 2006 with workers from public emergency health service in Belo Horizonte, Brazil. The structured questionnaire developed for this study included the following items: a) demographics (occupation, gender, age, years of professional experience, years of work at public emergency service); b) knowledge- and attitude-related issues regarding infection control, universal precautions, and factors that affect the compliance to these measures; and c) occupational accidents involving biological substances.

Knowledge was defined as a piece of information, formal understanding or notion about infection control and recommendations about biosafety ${ }^{(8)}$. The information regarding the required knowledge was interpreted according to the principles that guide quality-care praxis, with a view to reducing occupational hazards. Moreover, references regarding occupational safety and universal precaution measures recommended by the CDC were also used.

As for inadequate knowledge, it was interpreted as the information about specific issues that was not in harmony with scientific literature. To analyze the knowledge between adopting precaution and infection control measures at the emergency service, the following items were selected: transmission vehicle of infectious agents; recommending the use of disposable gloves in pre-hospital care; recommending handwashing before caring for patients; handwashing when caring for patients in coma; risk of infection with the ocular mucosa as a door for infectious agents; risk for crossed infection during procedures through venous access; diseases that can be acquired due to the occupation's characteristic in pre-hospital care; specific universal precautions for prehospital care; where the waste produced during pre-hospital care is disposed; adequate conduct performed with the professional after the accident involving exposure to biological substances; comprehensive vaccine scheme for Hepatitis B; and comprehensive vaccine scheme for tetanus.

On the other hand, attitude was defined as one's response or reaction toward the infection control principles or recommendations about biosafety ${ }^{(8)}$. The response to the adequate attitude was verified in a hypothetical situation described considering the behavior that is expected during the service. This behavior is in harmony with the guidelines for quality healthcare practice and reducing occupational hazards as well as with the references regarding occupational safety and universal precaution measures recommended buy the CDC.

To analyze the attitude toward precaution measures, the following topics were selected: measures to reduce the transmission of infectious agents; recommending the use of masks and safety goggles; appropriately disposing of sharp-edged objects; and making adequate use of individual protection equipment when providing emergency services.

This instrument was validated by a group of experts in hospital infection control, epidemics, and occupational health. After reviewing the formulated questions, the instrument was carefully analyzed for clarity and content in telligibility, and the experts' suggested changes were made. The instrument was then administrated in a sample consisting of nurses, physicians, drivers; technicians; nursing auxiliaries and other emergency service workers. After the 
assessment, the instrument was forwarded to the same experts for their analysis and criticisms. This validation stage is yet to be published.

The validation results were examined item by item, and a general indicator of good knowledge and good attitude was created. The latter was defined as giving correct answers to more than $75 \%$ of the questions concerning knowledge and attitude.

These results were analyzed according to the participants' occupation (physicians, nurses, nursing auxiliaries, and drivers), age, gender, years of professional experience; years in the institution; and work location ${ }^{(9)}$. In addition, to analyze the results, the public emergency services were assigned to two distinct groups, according to the Health Ministry Regulation 2.048/2002, basic support unit (care to victims at the place of the accident and transportation of patients with risk of death), and advanced support unit (care to victims that require complex invasive procedures for life maintenance) ${ }^{(1)}$.

Chi-square tests were used to compare category variables. Univariate analysis with logistic regression was used to evaluate possible associations between adopting precaution measures and occupational accidents. Variables with a significance level at $25 \%$ were analyzed using the multivariate model, and only those with a $5 \%$ significance level remained in the final model.

Logistic regression results were reported as coefficients with confidence intervals of $95 \%$ (CI95). For all tests, p values under 0.05 were considered statistically significant. The statistical analyses were performed using SSPS 13.5 (statistical package for social sciences).

The proposed study was presented to and approved by the Ethics Committee at Federal University of Minas Gerais (File \#458/05).

\section{RESULTS}

Our sample includes complete answers from 238 participants, who belonged to the multiprofessional team. It was comprised by physicians (14.3\%), nurses (10.5\%), nursing auxiliaries (47.5\%), and drivers (27.7\%). In the sample in which $66.8 \%$ were men, $58.4 \%$ had up to two years of work experience at the facility, and $69.7 \%$ worked in the basic care unit.

Table 1 displays the proportion of correct answers to knowledge; items regarding universal precautions.

Table 1 - Distribution of the answers about knowledge regarding universal precaution measures according to the participant's occupation - Belo Horizonte, Brazil - 2006

\begin{tabular}{|c|c|c|c|c|c|}
\hline Knowledge & $\begin{array}{c}\text { Physician } \\
\text { N = 34 } \\
(\%)\end{array}$ & $\begin{array}{c}\text { Nurse } \\
\mathrm{N}=25 \\
(\%)\end{array}$ & $\begin{array}{c}\text { Nursing } \\
\text { auxiliary } \\
\mathrm{N}=113(\%)\end{array}$ & $\begin{array}{c}\text { Driver } \\
N=66 \\
(\%)\end{array}$ & p-value ${ }^{1}$ \\
\hline $\begin{array}{l}\text { Recommending the use of disposable gloves } \\
\text { in emergency service }\end{array}$ & $\begin{array}{c}31 \\
(91.2)\end{array}$ & $\begin{array}{c}24 \\
(96.0)\end{array}$ & $\begin{array}{c}87 \\
(77.0)\end{array}$ & $\begin{array}{c}35 \\
(53.0)\end{array}$ & $<0.01$ \\
\hline Importance of hand washing & $\begin{array}{c}32 \\
(94.1)\end{array}$ & $\begin{array}{c}21 \\
(84.0)\end{array}$ & $\begin{array}{c}98 \\
(86.7)\end{array}$ & $\begin{array}{c}42 \\
(63.6)\end{array}$ & $<0.01$ \\
\hline $\begin{array}{l}\text { Recommending handwashing when taking care } \\
\text { of any patient }\end{array}$ & $\begin{array}{c}26 \\
(76.5)\end{array}$ & $\begin{array}{c}21 \\
(84.0)\end{array}$ & $\begin{array}{c}95 \\
(84.1)\end{array}$ & $\begin{array}{c}53 \\
(80.3)\end{array}$ & 0.749 \\
\hline $\begin{array}{l}\text { Risk of infection by contact between blood and } \\
\text { the ocular mucosa }\end{array}$ & $\begin{array}{c}27 \\
(79.4)\end{array}$ & $\begin{array}{c}18 \\
(72.0)\end{array}$ & $\begin{array}{c}55 \\
(48.7)\end{array}$ & $\begin{array}{c}28 \\
(42.4)\end{array}$ & 0.001 \\
\hline $\begin{array}{l}\text { Risk of crossed transmission of infectious agents } \\
\text { when accessing peripheral veins }\end{array}$ & $\begin{array}{c}29 \\
(85.3)\end{array}$ & $\begin{array}{c}18 \\
(72.0)\end{array}$ & $\begin{array}{c}81 \\
(71.7)\end{array}$ & $\begin{array}{c}39 \\
(59.1)\end{array}$ & 0.051 \\
\hline $\begin{array}{l}\text { Possible infection due to contact with body fluids } \\
\text { and blood }\end{array}$ & $\begin{array}{c}34 \\
(100.0)\end{array}$ & $\begin{array}{c}22 \\
(88.0)\end{array}$ & $\begin{array}{c}75 \\
(66.4)\end{array}$ & $\begin{array}{c}34 \\
(51.5)\end{array}$ & $<0.01$ \\
\hline Universal precaution in pre-hospital care & $\begin{array}{c}20 \\
(58.8)\end{array}$ & $\begin{array}{c}19 \\
(76.0)\end{array}$ & $\begin{array}{c}64 \\
(56.6)\end{array}$ & $\begin{array}{c}42 \\
(63.6)\end{array}$ & 0.322 \\
\hline $\begin{array}{l}\text { Adequate disposal of waste produced at the } \\
\text { emergency service }\end{array}$ & $\begin{array}{c}24 \\
(70.6)\end{array}$ & $\begin{array}{c}21 \\
(84.0)\end{array}$ & $\begin{array}{c}86 \\
(76.1)\end{array}$ & $\begin{array}{c}47 \\
(71.2)\end{array}$ & 0.579 \\
\hline $\begin{array}{l}\text { Measures following a occupational accident } \\
\text { involving sharp-edged objects or body fluids }\end{array}$ & $\begin{array}{c}30 \\
(88.2)\end{array}$ & $\begin{array}{c}21 \\
(84.0)\end{array}$ & $\begin{array}{c}98 \\
(86.7)\end{array}$ & $\begin{array}{c}54 \\
(81.8)\end{array}$ & $0.799 *$ \\
\hline Vaccination against hepatitis B & $\begin{array}{c}33 \\
(97.1)\end{array}$ & $\begin{array}{c}22 \\
(88.0)\end{array}$ & $\begin{array}{c}101 \\
(89.4)\end{array}$ & $\begin{array}{c}53 \\
(80.3)\end{array}$ & $0.093 *$ \\
\hline
\end{tabular}

${ }^{1} \mathrm{p}$-value is related to the chi-square test. ${ }^{*}$ Fischer's exact test. 
Table 1 shows that physicians scored $85.3 \%$ on average; however, for items related to universal precaution and disposal of waste produced during care, scores were below $75 \%$. Nurses scored $83.2 \%$ on average; however for issues related to the risk of crossed transmission of infectious agents and the risk of infection by contact between blood and the eye, scores were below $75 \%$. Nursing auxiliaries scored $75.9 \%$ on average; but for issues concerning crossed infection, universal precautions, blood-transmitted diseases, and the risk of infection by contact between blood and the eye, scores were below $75 \%$. Drivers had the lowest level of knowledge compared to the other workers, scoring $65.0 \%$ (adequate answers) on average. They showed a lack of knowledge about almost all the items assessed, except for recommending handwashing, care after accidents with sharp-edged objects, and vaccination against hepatitis $B$.

It is emphasized that, compared to other workers, only physicians scored over $75 \%$ of adequate answers regard- ing the items concerning risk of infection by contact between blood and the ocular mucosa and risk of crossed transmission of infectious agents when accessing peripheral veins.

In addition, there was a statistically significant difference among occupations regarding the vehicle for transmitting infectious agents, recommending the use of disposable gloves at the emergency service, importance of handwashing, infection risk by contact between blood and the ocular mucosa; and possible infection due to contact with body fluids and blood $(p<0.01)$.

Table 2 shows the ratio of correct answers for items concerning attitude toward universal precautions. Overall, no statistically significant association was found between mean attitude and each occupational category's knowledge level, although nurses and drivers scored below $75 \%$.

Table 2 - Distribution of the answers regarding attitude toward universal precaution measures

\begin{tabular}{|c|c|c|c|c|c|}
\hline Attitude & $\begin{array}{c}\text { Physician } \\
N=34 \\
(\%)\end{array}$ & $\begin{array}{c}\text { Nurse } \\
\mathrm{N}=25 \\
(\%)\end{array}$ & $\begin{array}{c}\text { Nursing } \\
\text { auxiliary } \\
\mathbf{N}=113(\%)\end{array}$ & $\begin{array}{c}\text { Driver } \\
\mathrm{N}=66 \\
(\%)\end{array}$ & p-value ${ }^{1}$ \\
\hline $\begin{array}{l}\text { Measures to reduce the transmission of } \\
\text { infectious agents }\end{array}$ & $\begin{array}{c}29 \\
(85.3)\end{array}$ & $\begin{array}{c}16 \\
(76.0)\end{array}$ & $\begin{array}{c}94 \\
(83.2)\end{array}$ & $\begin{array}{c}48 \\
(72.7)\end{array}$ & 0.296 \\
\hline $\begin{array}{l}\text { Recommending the use of face masks } \\
\text { and safety goggles }\end{array}$ & $\begin{array}{c}24 \\
(70.6)\end{array}$ & $\begin{array}{c}11 \\
(44.0)\end{array}$ & $\begin{array}{c}78 \\
(69.0)\end{array}$ & $\begin{array}{c}34 \\
(51.5)\end{array}$ & 0.018 \\
\hline Adequate disposal of sharp-edged material & $\begin{array}{c}33 \\
(97.1)\end{array}$ & $\begin{array}{c}24 \\
(96.0)\end{array}$ & $\begin{array}{c}102 \\
(90.3)\end{array}$ & $\begin{array}{c}35 \\
(53.0)\end{array}$ & $<0.01$ \\
\hline $\begin{array}{l}\text { Use of adequate individual protection } \\
\text { equipment during emergency service }\end{array}$ & $\begin{array}{c}22 \\
(64.7)\end{array}$ & $\begin{array}{c}17 \\
(68.0)\end{array}$ & $\begin{array}{c}72 \\
(63.7)\end{array}$ & $\begin{array}{c}41 \\
(62.1)\end{array}$ & 0.965 \\
\hline Mean & $\begin{array}{c}27 \\
(79.4)\end{array}$ & $\begin{array}{c}18 \\
(71.0)\end{array}$ & $\begin{array}{c}86 \\
(76.5)\end{array}$ & $\begin{array}{c}39 \\
(59.8)\end{array}$ & 0.076 \\
\hline
\end{tabular}

${ }^{1} \mathrm{p}$-value is related to the chi-square test.

As shown in Table 2, no occupational categories scored over $75 \%$ (adequate answers) on the items: using a face mask and safety goggles; and adequate individual protection equipment during emergency care service. There was a statistically significant difference among the staff members for items concerning the recommendation for using face masks, safety goggles, and the appropriate disposal of sharp-edged material $(p<0.01)$. During pre-hospital care, nurses and drivers did not use face masks and safety goggles, different from physicians and nursing technicians/ auxiliaries. Furthermore, compared to the other workers, drivers did not follow appropriate measures to dispose of sharp-edged objects $(p<0.01)$.

Table 3 displays the answers to questions about occupational accidents due to the exposure to biological substances among the multiprofessional team workers. The global incidence of occupational accidents was categorized by over the last year was $20.6 \%$. The average accident rates for staff members were as follows: body fluid contact$49.0 \%$; involving sharp-edged objects $-40.8 \%$; and involv- ing both contact with body fluids and handling sharp-edged objects $-10.2 \%$. A medical evaluation after accidents was done in $36.7 \%$ of cases, and the occupational accident report was issued for $18.4 \%$ of victims. No measure was undertaken in $55.1 \%$ of cases, and serological monitoring was not completed in $61.2 \%$ of accident victims.

The analysis of occupational accidents involving biological material, per occupation, revealed that $35.3 \%$ of physicians were involved in accidents; $83.3 \%$ of cases were related to body fluid contact. No medical intervention was followed in any cases. Serological monitoring was done in $16.7 \%$ of these accident victims during one year. An important point is that no occupational accident reports were issued in any of these accidents. Among nurses, the occupational accident rate was $24.0 \%$. Of these, $50.0 \%$ involved sharp-edged materials, $33.3 \%$ resulted from contact with body fluids, and $16.7 \%$ had both forms of contact. A medical evaluation was performed in only $33.3 \%$ of cases, and no occupational accident report was issued. Serological monitoring during one year was also not done in any of these cases (Table 3). 
Table 3 - Rates of occupational accidents involving exposure to biological substances and assessment/management after the accident, per occupation - Belo Horizonte, Brazil - 2006

\begin{tabular}{|c|c|c|c|c|}
\hline Occupational accidents & $\begin{array}{l}\text { Physician } \\
\mathrm{N}=\mathbf{3 4} \\
(\%)\end{array}$ & $\begin{array}{l}\text { Nurse } \\
\mathrm{N}=25 \\
(\%)\end{array}$ & $\begin{array}{l}\text { Nursing auxiliary } \\
\mathrm{N}=113 \\
(\%)\end{array}$ & $\begin{array}{l}\text { Driver } \\
\mathrm{N}=66 \\
(\%)\end{array}$ \\
\hline \multicolumn{5}{|l|}{ Occupational accident over the last year } \\
\hline No & $\begin{array}{c}22 \\
(64.7)\end{array}$ & $\begin{array}{c}19 \\
(76.0)\end{array}$ & $\begin{array}{c}93 \\
(82.3)\end{array}$ & $\begin{array}{c}55 \\
(83.3)\end{array}$ \\
\hline Yes & $\begin{array}{c}12 \\
(35.3)\end{array}$ & $\begin{array}{c}6 \\
(24.0)\end{array}$ & $\begin{array}{c}20 \\
(17.7)\end{array}$ & $\begin{array}{c}11 \\
(16.7)\end{array}$ \\
\hline \multicolumn{5}{|l|}{ Form of contact } \\
\hline Body fluids & $\begin{array}{c}28 \\
(83.3)\end{array}$ & $\begin{array}{c}8 \\
(33.3)\end{array}$ & $\begin{array}{c}51 \\
(45.0)\end{array}$ & $\begin{array}{c}18 \\
(27.3)\end{array}$ \\
\hline Sharp-edged objects & $\begin{array}{c}7 \\
(16.7)\end{array}$ & $\begin{array}{c}13 \\
(50.0)\end{array}$ & $\begin{array}{c}40 \\
(35.0)\end{array}$ & $\begin{array}{c}48 \\
(72.7)\end{array}$ \\
\hline Both & $\begin{array}{c}0 \\
(0.0)\end{array}$ & $\begin{array}{c}4 \\
(16.7)\end{array}$ & $\begin{array}{c}22 \\
(20.0)\end{array}$ & $\begin{array}{c}0 \\
(0.0)\end{array}$ \\
\hline \multicolumn{5}{|l|}{ Medical assessment after accident } \\
\hline Yes & $\begin{array}{c}7 \\
(16.7)\end{array}$ & $\begin{array}{c}8 \\
(33.3)\end{array}$ & $\begin{array}{c}34 \\
(30.0)\end{array}$ & $\begin{array}{c}48 \\
(72.7)\end{array}$ \\
\hline No & $\begin{array}{c}28 \\
(83.3)\end{array}$ & $\begin{array}{c}17 \\
(66.7)\end{array}$ & $\begin{array}{c}79 \\
(70.0)\end{array}$ & $\begin{array}{c}18 \\
(27.3)\end{array}$ \\
\hline \multicolumn{5}{|l|}{ Occupational accident report } \\
\hline Yes & $\begin{array}{c}0 \\
(0.0)\end{array}$ & $\begin{array}{c}0 \\
(0.0)\end{array}$ & $\begin{array}{c}23 \\
(20.0)\end{array}$ & $\begin{array}{c}30 \\
(45.5)\end{array}$ \\
\hline No & $\begin{array}{c}34 \\
(100.0)\end{array}$ & $\begin{array}{c}25 \\
(100.0)\end{array}$ & $\begin{array}{c}90 \\
(80.0)\end{array}$ & $\begin{array}{c}36 \\
(54.5)\end{array}$ \\
\hline \multicolumn{5}{|l|}{ Management immediately after the accident } \\
\hline $\begin{array}{l}\text { Quick HIV test for the patient, positive result. } \\
\text { Use of retroviral medication during the first } 2 \mathrm{~h} \\
\text { following the accident }\end{array}$ & $\begin{array}{c}0 \\
(0.0)\end{array}$ & $\begin{array}{c}0 \\
(0.0)\end{array}$ & $\begin{array}{c}6 \\
(5.0)\end{array}$ & $\begin{array}{c}0 \\
(0.0)\end{array}$ \\
\hline
\end{tabular}

The occupational accident rate involving biological substances was $17.7 \%$ among nursing technicians/auxiliaries; $45.0 \%$ of these cases involved contact with body fluids, $35.0 \%$ occurred with sharp-edged objects, and $20.0 \%$ involved both. A medical evaluation was performed in $30.0 \%$ of the accidents, and the occupational accident report was issued for $20.0 \%$ of workers. Among the staff that underwent medical evaluation, $25.0 \%$ were monitored by serology for one year. Drivers had the smallest accident rate (16.7\%). Of these cases, $72.7 \%$ involved sharp-edged objects, and medical assessments were carried out in every one. However, only $45.5 \%$ of the accidents were reported, and only $9.1 \%$ of the assessed workers were monitored by serology for one year (Table 3).

The univariate logistic regression analysis (Table 4) revealed that the variables occupation, gender, and work location were significantly associated $(p<0.05)$ with the compliance or not of universal precaution measures. The estimated probability of not adopting precaution measures was 20.7 (CI 95\%: 5.68- 75.14) times higher among drivers compared to physicians, 2.2 (IC 95\%: 1,22- 4,10) times higher in men compared to women, and 3.5 (IC 95\%: 1,77-6,82) times higher in workers located in the primary care unit compared to workers located in the advanced care unit.

Table 4 - Results of multivariate logistic regression regarding the non-compliance to precaution measures and occupational accidents - Belo Horizonte, Brazil - 2006

\begin{tabular}{|c|c|c|c|c|}
\hline \multirow[t]{2}{*}{ Model variables } & \multicolumn{3}{|c|}{$\begin{array}{c}\text { Panel A - Multivariate analysis: } \\
\text { non-compliance to precaution measures } \\
\text { among those who have correct knowledge levels }\end{array}$} & \multirow{2}{*}{$\begin{array}{c}\text { Panel B - Univariate analysis: } \\
\text { work accidents } \\
\text { Odds Ratio (IC) }\end{array}$} \\
\hline & Coefficient & Odds Ratio (IC) & p-value & \\
\hline \multicolumn{5}{|l|}{ Profession } \\
\hline Nurse & 1083 & $2.95(0.25-34.68)$ & 0.389 & $1.58(0.51-4.86)$ \\
\hline Nursing auxiliary & 1103 & $3.01(0.35-25.54)$ & 0.312 & $1.08(0.48-2.41)$ \\
\hline Driver & 2099 & $8.6(0.89-75.24)$ & 0.06 & 1.00 \\
\hline Physician & & & & $2.73(1.05-7.09)$ \\
\hline Constant & -3434 & & $<0.01$ & \\
\hline
\end{tabular}


The multivariate logistic regression analysis considering demographic variables showed that drivers and nursing auxiliaries were statistically associated with the noncompliance to precaution measures. Since there is a difference among occupations regarding knowledge, the analysis was restricted to those who answered knowledge-questions correctly. In this case, drivers were associated with non-compliance to precaution measures at the level of $10 \%$ (Table 4, panel A).

The univariate logistic regression analysis for occupational accidents revealed that the estimated chance of physicians having a work-related accident was 2.7 (IC95\%: (1.057.09) times higher than that of drivers (Table 4, panel B).

\section{DISCUSSION}

In respect to the workers' knowledge level, it was observed that most did not provide correct answers to the question regarding precaution measures inherent to the emergency care service. At the $5 \%$ level, there was no statistically significant association between the mean knowledge level and the occupation $(p=0.094)$, although drivers had a lower rate of correct answers in most questions. It can be inferred that the workload often keeps workers from consulting the guidelines and implementing them in their practice ${ }^{(9-10)}$.

Overall, analyzing knowledge by occupation showed that drivers were the only workers who did not reach the mean level of $75 \%$ of adequate answers. The differences regarding knowledge, in a multiprofessional tem, can be explained in part by the different educational approaches in each of these workers. Drivers are required to have the skill to drive quickly and safely. However, they also participate by performing less complex procedures, thus becoming exposed to the same occupational risks of the other workers.

According to the Centers for Disease Control and Prevention (CDC), any emergency service worker, whose job implies contact with blood and other body fluids, should receive information about biosafety during work hours, and participate in yearly courses ${ }^{(3,11)}$. In addition, preventive programs should develop and implement policies and procedures to manage occupational risks, with a view to reducing the individual differences concerning knowledge in the health team ${ }^{(3)}$.

In the attitude analysis, none of the occupations reached $75 \%$ of adequate answers for the recommendation of using safety goggles and individual protection equipment during emergency services. Adopting precaution measures helps to control the dissemination of pathogens; the use of individual protection equipment is essential for protecting the emergency service worker in the public. Although the use of individual protection equipment does not keep the worker from having an accident, it does help to reduce the exposure to risk ${ }^{(12)}$. The investigation showed that the reality of complying with precaution measures is far from being that which is recommended ${ }^{(13-14)}$.
The global incidence of occupational accidents among public emergency care service workers exposed to biological material was $20.6 \%$. Other authors have reported rates of health workers involved in accidents with exposure to biological material varying from $18.4 \%$ to $100 \%^{(15-16)}$. Health workers are exposed to occupational accidents caused mostly by sharp-edged materials and contact with body fluids. In public emergency care services, the worker is constantly exposed to occupational hazards, particularly when handling the bodily excretions and secretions of patients potentially carrying unknown diseases, who may become the source of transmission of microorganisms for the worker and/or other victims ${ }^{(15)}$

Surprisingly, medical assessments were performed in $36.7 \%$ of public emergency care service workers victims of occupational accidents; and, accident reports were issued in $18.4 \%$ of cases. These rates are similar to those found in previous studies ${ }^{(16-17)}$. The difference in accident rates observed among occupations can be justified by the presence of physicians and nurses in advanced support units. Furthermore, during emergency care, the activities performed by physicians constantly expose them to the contact with blood and body fluids, whereas nurses perform several activities that involve sharp-edged objects.

On the other hand, drivers perform less complex activities, although after providing emergency care they help the nursing team to clean the ambulances and dispose of the sharp-edged material that was used. For this reason, this group presented the highest rate of accidents with sharpedged objects.

Although drivers deal with ill people, accident victims, and sharp objects, it is observed there is a lack of knowledge regarding exposure to contagious diseases, serologic tests $^{(12)}$ and post-accident follow-up, since this group presented the highest level of medical assessments after accidents with sharp-edged material. Workers who reported occupational accidents are those who presented multiple lesions and those who think that cleaning the wound immediately is enough ${ }^{(9)}$.

In this study, workers with the highest levels of specific knowledge (physicians and nurses) had a higher rate of adequate answers regarding precaution measures. Physicians, however, had the highest rate of accidents involving body fluids. This suggests that the level of knowledge did not have any effect over the use of individual protection equipment against occupational accidents.

It is evident that complying with safe practices is ultimately the result of a multitude of factors; some are immeasurable or impossible to change. The factors that were not included in this study regard the non-observation of workers' compliance ${ }^{(9)}$.

The logistic regression analysis revealed that drivers often did not comply with universal precaution measures 
compared to other public emergency services. This can be justified by the different forms of training that each of these professionals get, besides the fact that drivers do not receive any specific instruction in health sciences.

\section{CONCLUSION}

Based on these results, it is concluded that there was no association between complying with precaution measures and public emergency service workers. However, it was observed there are differences among them regarding their knowledge and attitude. The rates for the item knowledge applied to infectious agents, in general, were over $75 \%$; the attitude toward the item precaution measures was gen-

\section{REFERENCES}

1. Brasil. Ministério da Saúde. Portaria n. 737 , de 16 de maio de 2001. Dispõe sobre a Política Nacional de Redução da Morbimortalidade por Acidentes e Violências. Diário Oficial da União, Brasília, DF, 17de maio de 2001.

2. Barrios JP, Pérez IO, Cabal FC. Sistema médico prehospitalario de emergencia especializado en Medicina Crítica, a 10 años de operación en la ciudad de México. Neumol Cir Tórax. 2000;59(4):102-8.

3. Centers for Disease Control [CDC]. Guideline for Isolation Precautions: Preventing Transmission of Infectious Agents in Healthcare Settings [text on the Internet]. 2007. [cited 2007 Sept. 15]. Available from: http://www.cdc.gov/ncidod/dhqp/pdf/ isolation2007.pdf

4. Garner JS. Hospital Infection Control Practices Advisory Commitee. Guideline for isolation precautions in hospitals. Infect Control Hosp Epidemiol. 1996;17(2):53-80.

5. Phipps W, Honghong W, Min Y, Burgess J, Pellico L, Atkins CW, et al. Risk of medical sharps injuries among chinese nurses. Infect Control Hosp Epidemiol. 2006;34(4):277-82.

6. Brevidelli MM, Cianciarullo TI. Compliance with standardprecautions among medical and nursing staff at a university hospital. Online Braz J Nurs [serial on the Internet].2006 [cited 2006 Nov. 20];5(1). Available from: http://www.uff.br/objnursing/ index.php/nursing/article/view/291

7. Kermode M, Jolley D, Langkham B, Thomas MS, Holmes W, Gifford SM. Compliance with Universal/Standard Precautions among health care workers in rural north India. Am J Infect Control. 2005;33(1):27-33.

8. Sax $H$, Perneger T, Hugonnet $S$, Herrault $P$, Chraiti MN, Pittet $D$. Knowledge of standard and isolation precautions in a large teaching Hospital. Infect Control Hosp Epidemiol. 2005;26(3):298-304.

9. Askarian M, Shiraly R, McLaws ML. Knowledge, attitudes and practices of contact precautions among Iranian nurses. Infect Control Hosp Epidemiol. 2005;33(8):486-8. erally below $75 \%$. The occupational accident rate was $20.6 \%$ (40.8\% involving sharp-edged objects). The estimated probability of physicians becoming involved in an accident was 2.7 times greater that that of drivers. The fact that the worker has knowledge about adequate precaution measures, infection control, and occupational risks was not enough to promote attitudes that would be compatible with reducing the risk of transmitting infectious agents and causing occupational accidents.

Continuous education programs are suggested to improve knowledge about precaution measures. The purpose would be to reduce the exposure of public emergency service users and occupational risks agents, along with a formal program to supervise and follow the injured workers.

10. Cooper S, O'Carroll J, Jenkin A, Badger B. Collaborative practices in unscheduled emergency care: role and impact of the emergency care practitioner-qualitative and summative findings. Emerg Med J. 2007;24(9):625-9.

11. Brandi S, Benatti MCC, Alexandre NMC. Ocorrência de acidente do trabalho por material perfurocortante entre trabalhadores de enfermagem de um hospital universitário da cidade de Campinas, Estado de São Paulo. Rev Esc Enferm USP. 1998;32(2):124-33.

12. Angtuaco TL, Oprescu FG, Lal SK, Pennington JH., Russell BD, $\mathrm{CO} \mathrm{JM}$, et al. Universal precautions guidelines: self-reported compliance by gastroenterologists and gastrointestinal endoscopy nurses - a decade's lack of progress. Am J Gastroenterol. 2003;98(11):2420-3.

13. Cutter J, Jordan S. Uptake of guidelines to avoid and report exposure to blood and body fluids. J Adv Nurs. 2004;46(4):441-52.

14. Florêncio VB, Rodrigues $C A$, Pereira MS, Souza ACS. Adesão às precauções padrão entre os profissionais da Equipe de Resgate Pré-Hospitalar do Corpo de Bombeiros de Goiás-Brasil. Rev Eletrônica Enferm [periódico na Internet]. 2003 [citado 2006 nov. 19];5(1):[cerca de 6 p.]. Disponível em: http://www.fen.ufg.br/ revista/revista5_1/pdf/adesao.pdf

15. Memish ZA, Almuneef M, Dillon J. Epidemiology of needlestick and sharps injuries in a tertiary care center in Saudi Arabia. Infect Control Hosp Epidemiol. 2002;30(4):234-41.

16. Nishide VM, Benatti MAC, Alexandre NMC. Ocorrência de acidente do trabalho em uma Unidade de Terapia Intensiva. Rev Lat Am Enferm. 2004;12(2):204-11.

17. Doebbeling B, Vaughn TE, McCoy KD, Beekmann SE, Woolson $\mathrm{RF}$, Ferguson KJ, et al. Percutaneous injury, blood exposure, and adherence to standard precautions: are hospital-based health care providers still at risk? Clin Infect Dis. 2003;37(8):1006-13. 